\title{
Viewpoint \\ Gata-3 and mammary cell fate
}

Matthew J Naylor and Christopher J Ormandy

Cancer Research Program, Garvan Institute of Medical Research, Victoria Street, Darlinghurst, NSW 2010 Australia

Corresponding author: Christopher J Ormandy, c.ormandy@garvan.org.au

Published: 19 March 2007

This article is online at http://breast-cancer-research.com/content/9/2/302

(c) 2007 BioMed Central Ltd
Breast Cancer Research 2007, 9:302 (doi:10.1186/bcr1661)

immune system, kidney and other tissues. Constitutive null mutation of Gata-3 results in embryonic lethality. In the mammary gland Gata-3 is expressed only by the epithelium and its expression increases during early pregnancy [4]. Recent work from Zena Werb's laboratory [5] reports that Gata-3 was the most highly enriched transcription factor in a microarray analysis of terminal end-buds and ducts compared to epithelium free stroma. Gata-3 expression can be detected as early as E12.5 in primordial mammary buds of Gata-3/ LacZ knockin mice [6]. Expression in mammary epithelium continues throughout puberty and pregnancy and Gata-3 expression is restricted to luminal cell lineages. The expression and localisation of Gata-3 indicates a potential role in the regulation of epithelial cell phenotype throughout several stages of mammary gland development.

\section{Gata-3 knockout}

Using the Cre/lox system, both the Werb and Visvader labs demonstrated a critical role for Gata-3 in the regulation of several stages of mammopoiesis. Deletion of Gata-3 driven by $\mathrm{K} 14-\mathrm{Cre}$ (expressed in mammary primordia) resulted in the failure to form mammary placodes [6]. This finding is similar to that observed following loss of the LEF1, Msx1 and Msx2 transcription factors [7] and may indicate a transcriptional network or complex between these molecules.

Defects in ductal elongation and invasion through the mammary fat pad were observed in both studies following MMTV-Cre induced deletion of Gata-3 $[5,6]$. This phenotype is similar to that observed following loss of oestrogen receptor $\alpha$. Interestingly, Gata-3 has previously been shown to orchestrate transcriptional networks in other systems [8], and it appears to have a similar function in the mammary gland. Gata-3 binds to the promoter of FoxA1, a forkhead factor that is required for chromatin binding of oestrogen receptor [2,5]. This indicates a transcriptional network in which Gata-3 regulates the transcriptional activity of oestrogen receptor $\alpha$, and identifies Gata-3 as a potential master regulator of ductal elongation at puberty.

In addition to regulating mammary placode formation and ductal elongation, a direct requirement for Gata-3 in epithelial

\section{Gata-3}

The Gata family comprises six zinc-finger transcription factors that have a well-defined role in cell-fate specification in the 
cell differentiation was demonstrated. Deletion of Gata-3 following mammary ductal development resulted in failure of the expansion of the luminal progenitor population required for lobuloalveolar development during pregnancy [6]. This finding was supported by the ability of Gata-3 expression to drive a stem cell enriched population along the alveolar luminal lineage. This is one of the first findings linking a transcription factor to the enriched luminal cell progenitor population it regulates. In this context it will be interesting to determine which progenitor cell populations are acted upon by other known transcriptional regulators of mammary development such as Stat5 or C/EBP $\beta$.

The failure of the luminal progenitor population expansion following Gata-3 loss resulted in the accumulation of undifferentiated luminal cells, characterised by an absence of differentiation markers such as $\beta$ casein $[5,6]$. The resulting outcome was a failure of differentiation manifested as impaired lactation. Several other knockout mice also display a similar phenotype, most notably members of the prolactin signalling pathway, such as Stat5 and Elf5, and molecules that feed into this pathway or are markers of mammary stem cells, such as $\beta 1$ integrin. In prolactin receptor knockouts, which also display a failure of lobuloalveolar development, Gata-3 expression is greatly reduced $[4,9]$. Whether or not Stat5, Elf5 or Gata-3 or others physically interact or are members of the same transcriptional network remains to be determined, as does their order in the cascade from hormonal stimulus to execution of de novo transcription. Reduced Gata-3 expression in prolactin receptor null mammary glands may simply indicate the loss of Gata-3 cell populations in these glands or, conversely, that Gata-3 is a true downstream target of the prolactin pathway. What is clear, however, is that although many transcription factors will prove essential for this process, no one transcription factor is likely to act alone. Rather, these transcription factors will act as part of a coordinated transcriptional network, providing an integrated response to multiple extracellular stimuli.

In addition to demonstrating that Gata-3 is a key regulator of mammary gland development, the Werb and Visvader studies also raise the interesting question of the role of Gata-3 in breast cancer. Consistent with similar mammary gland phenotypes and the link to FoxA1, expression of Gata-3 correlates with estrogen receptor- $\alpha$ in microarray studies of human breast cancer [10]. High Gata-3 expression was a marker for well-differentiated tumours, while low Gata-3 expression was strongly associated with markers of poor patient prognosis, such as oestrogen receptor and progesterone receptor negative status, high histological grade and ErbB2 over-expression. The potential utility of Gata-3 as a prognostic indicator has also been verified by meta-analysis [11]. In addition, mutations in Gata-3 have been reported in a subset of breast tumours, indicating a potential tumour suppressor role [12]. These studies, together with the Gata-3 regulatory role during mammary gland development strongly support further studies into the role of Gata-3 in human breast cancer.

\section{Competing interests}

The authors declare that they have no competing interests.

\section{References}

1. Lee TI, Rinaldi NJ, Robert F, Odom DT, Bar-Joseph Z, Gerber GK Hannett NM, Harbison CT, Thompson CM, Simon I, et al.: Transcriptional regulatory networks in Saccharomyces cerevisiae. Science 2002, 298:799-804.

2. Carroll JS, Liu XS, Brodsky AS, Li W, Meyer CA, Szary AJ, Eeckhoute J, Shao W, Hestermann EV, Geistlinger TR, et al:: Chromosome-wide mapping of estrogen receptor binding reveals long-range regulation requiring the forkhead protein FoxA1. Cell 2005, 122:33-43.

3. Visvader JE, Lindeman GJ: Transcriptional regulators in mammary gland development and cancer. Int J Biochem Cell Biol 2003, 35:1034-1051.

4. Ormandy CJ, Naylor M, Harris J, Robertson F, Horseman ND, Lindeman GJ, Visvader J, Kelly PA: Investigation of the transcriptional changes underlying functional defects in the mammary glands of prolactin receptor knockout mice. Recent Prog Horm Res 2003, 58:297-323.

5. Kouros-Mehr H, Slorach EM, Sternlicht MD, Werb Z: GATA-3 maintains the differentiation of the luminal cell fate in the mammary gland. Cell 2006, 127:1041-1055.

6. Asselin-Labat ML, Sutherland KD, Barker H, Thomas R, Shackleton M, Forrest NC, Hartley L, Robb L, Grosveld FG, van der Wees $\mathrm{J}$, et al.: Gata-3 is an essential regulator of mammary-gland morphogenesis and luminal-cell differentiation. Nat Cell Biol 2007, 9:201-209.

7. Hens JR, Wysolmerski JJ: Key stages of mammary gland development: molecular mechanisms involved in the formation of the embryonic mammary gland. Breast Cancer Res 2005, 7: 220-224.

8. Grogan JL, Locksley RM: T helper cell differentiation: on again, off again. Curr Opin Immunol 2002, 14:366-372.

9. Harris J, Stanford PM, Sutherland K, Oakes SR, Naylor MJ, Robertson FG, Blazek KD, Kazlauskas M, Hilton HN, Wittlin S, et al.: Socs2 and elf5 mediate prolactin-induced mammary gland development. Mol Endocrinol 2006, 20:1177-1187.

10. Oncomine [www.oncomine.org]

11. Mehra R, Varambally $S$, Ding $L$, Shen $R$, Sabel MS, Ghosh $D$, Chinnaiyan AM, Kleer CG: Identification of GATA3 as a breast cancer prognostic marker by global gene expression metaanalysis. Cancer Res 2005, 65:11259-11264.

12. Usary J, Llaca V, Karaca G, Presswala S, Karaca M, He X, Langerod A, Karesen R, Oh DS, Dressler LG, et al.: Mutation of GATA3 in human breast tumors. Oncogene 2004, 23:76697678. 